DE DE GRUYTER

VOLUME 62, ISSUE 3, 2017, pp. 47-66

DOI: 10.1515/subboec-2017-0013

\title{
BANKS' VULNERABILITY AND FINANCIAL OPENNESS ACROSS CENTRAL AND EASTERN EUROPE
}

\author{
Simona NISTOR ${ }^{*}$ \\ Babeş-Bolyai University, Cluj Napoca, Romania
}

\begin{abstract}
This paper investigates the impact of the degree of capital account openness on banks' exposure to extreme events during the period 2005-2012 using a sample of financial institutions from Central and Eastern Europe. The empirical output highlights a positive and strongly significant impact of a higher degree of financial openness on banks' systemic vulnerability. Robust findings suggest that this harmful effect is lower for foreign owned banks or for those whose bank holding company signed one or more Vienna Initiative commitment letters. On the other side, tighter capital regulations and private monitoring policies enhance the positive impact of a higher degree of capital accounts openness on banks' vulnerability to systemic events.
\end{abstract}

JEL classification: G21, G28, G32

Keywords: banks' systemic vulnerability, financial openness, capital regulations.

\section{Introduction}

One of the most important effects generated by systemic events within the banking sector is the phenomena of contagion. Due to increased uncertainty financial shocks can propagate at an increased rate from one bank to another, making credit institutions more vulnerable to extreme events. From a macroprudential perspective, during stress periods the negative externalities transmitted through the financial network could significantly affect the stability of the financial system at the country level. Despite this severe threatening, regulatory policies are more oriented toward ex-ante prudential regulation on leverage and liquidity or restrictions on asset types and lending activities. The incorporation of network dependencies within these regulations is unsettled yet, even though the fact that they have been on the agenda of supervisory authorities in the last years.

\footnotetext{
* Corresponding author. Address: Babeş-Bolyai University, Faculty of Economics and Business Administration, Teodor Mihali Street, Nr. 58-60, Cluj-Napoca 400591, Romania, Telephone: +40264418652, E-mail: simona.mutu@econ.ubbcluj.ro
} 
A major role for the propagation of extreme shocks is played by cross-border capital transactions that reflect the openness of different financial networks. There is a large strand of literature that addresses theoretically the foundations of financial networks (Allen and Gale, 2000; Freixas et al., 2000; Babus, 2016), the anticipation of interbank contagion (Dasgupta, 2004) or contagion failures (Acemoglu et al., 2015).The underlying network structure can enhance the negative spillovers among banks, particularly for the institutions with similar balance sheet exposures. Fire sales of assets by a bank, for example, may induce negative externalities to other banks holding the same assets (Adrian and Shin, 2010). As do large withdrawals of liquidity (Allen and Gale, 2007) or collateral haircuts (Brunnermeier and Perdersen, 2009). Nevertheless, the complexity of interbank risk maturity structure (Filipović and Trolle, 2013) may generate a chain reaction within the network. Another important issue is related to the fact that spillovers within the network may develop endogenously through marking to market the asset book which may induce further rounds of forced sales (Cifuentes et al., 2005).

Empirically, the identification of the effect of cross-border capital transactions openness on banks' spillovers faces a number of challenges. Existing literature do not consider the effect of regulatory framework in a country on banks' headquartered in other countries. Also, despite the amplified interest on assessing the impact of financial openness on banks' distance to default and financial stability in general, there is little empirical evidence on the impact of cross cross-border capital transactions on bank' systemic vulnerability.

We aim to fill this gap by investigating the impact of financial openness on banks' exposure to extreme events (the vulnerability of banks' market assets to a downturn in the total market assets of the system). The sample we focus on includes some of the most important banks from CEE area with a higher share in total banking assets at the country level. The years analyzed cover the period 2005-2012 when high spillover vulnerabilities have been developed as a consequence of extreme events in the financial markets. The research question we aim to answer is: How financial openness affects the spread of contagion from the system to the banks?

Firstly, we estimate banks' systemic vulnerability based on the distributions of banks' and system's market assets returns using Quantile Regression models. Secondly, using an Ordinary Least Square model with FE we investigate the impact of the degree of capital account openness at the country level on banks' systemic vulnerability (de jure financial openness). Thirdly, we explore the effects of ownership, Vienna Initiative commitments, capital regulations and private monitoring on the relationship between financial openness and systemic vulnerability.

The output highlights a negative impact of a higher degree of capital account openness on banks' systemic vulnerability that is strongly significant. A one standard deviation increase in the Chinn-Ito index generates about 25 percent standard deviation increase in the systemic vulnerability index. The results are robust to different specifications that account for macroeconomic environment and bank characteristics, as well as for an asymmetric extension of the systemic vulnerability index.

Empirically, our research is related to the contributions to systemic importance measures like Systemic Expected Shortfall (SES) and the Marginal Expected Shortfall (MES) proposed by Acharya et al. (2012) based on banks' undercapitalization, the countercyclical prudential regulation highlighted by the Conditional Value at Risk (CoVaR) of Adrian and Brunnermeier (2016) or the SDSVaR method (State-Dependent 
Sensitivity VaR) developed by Adams et al. (2014) that reflects the contagion effects within different states of the economy. More recently, authors developed measures to identify SIFIs based on interbank positions (Drehmann and Tarashev, 2013), sovereign interlinkages (Correa et al., 2014), cross-border linkages (Minoiu et al., 2015) or network analysis (Cont et al., 2013; Hautsch et al., 2015; Betz et al., 2016). Also, this paper fits to research on regulatory incentives which highlight that financial stability can be significantly influenced by regulatory regimes (Wei $\beta$ et al., 2014), deposit insurance arrangements (Anginer et. al., 2014) or capital regulations (Bostandzic et al., 2014).

We aim to add to the literature on financial stability and financial openness. Our major contribution will reside in assessing to what extent the degree of capital account openness across CEE countries affect negative spillovers from the system to the banks. The impact of financial openness on banking sector stability has been previously investigated for both advanced and emerging economies, but the focus is on systemic contribution (the spread of contagion from a particular bank to the system during turbulent times). Our approach is different as we assess the impact on systemic vulnerability (the spread of contagion from the system to individual financial institutions). Also we explore the effects of different bank characteristics and the strength of the regulatory and monitoring framework to account for heterogeneity at the micro and macro level. In this line we add to the literature on financial stability and large foreign international groups' presence in emerging economies. To the best of our knowledge, this paper is the first that assesses the interplay between financial openness, foreign ownership status and systemic vulnerability across Central and Eastern European countries. Also, this paper provides new insights on the impact of the regulatory policies and financial openness link on banks' systemic vulnerability. Specifically, our empirical evidence emphasizes the role of tight capital regulations and restrictive private monitoring policies in controlling the exposure of banks to systemic events in countries with a lower degree of financial openness.

We proceed as follows: Section 2 provides the sample and the methodology, Section 3 describes the data, Section 4 discusses the empirical output, and, Section 5 concludes.

\section{Sample and methodology}

\subsection{Sample}

Our sample includes 25 banks that are publicly listed and represent 10 countries from Central and Eastern Europe. We started from a larger sample of more than 200 banks with data available in the Orbis database, but kept just the institutions that are listed on a stock exchange due to the requirement of market capitalization data for computing the systemic vulnerability indices. From a regulatory perspective these banks present importance at the national level, as they are classified among the top 5 banks by total assets within each country. About 70 percent of them are foreign owned and/or are part of a bank-holding company that signed one or more Vienna Initiative commitment letters. ${ }^{1}$

\footnotetext{
${ }^{1}$ Within the Vienna Initiative a number of banks from Western Europe with subsidiaries in CEE region signed commitment letters with the aim to maintain exposures in CEE banking system and support their subsidiaries during the financial crisis period.
} 
The period analyzed covers the years 2005-2012 when high spillover vulnerabilities have been developed in CEE region as a consequence of extreme events that affected the financial markets.

\subsection{Systemic vulnerability index}

For identifying systemically vulnerable banks we will focus on one of the most popular systemic importance measures, the Marginal Expected Shortfall (MES) of Acharya et al. (2010). This permits to assess the time-varying spillovers effects from the system to a particular bank under extreme conditions and identify systemically vulnerable financial institutions. The method implies a set of variables that combines balance sheet items (Total assets and Equity) and market data (Market capitalization).

First, we compute the market assets (MA) of each bank as the book value of total assets adjusted with the ratio of market value of equity to book value of equity. Second, the dependence of each bank's market assets returns on the system's returns is expressed using the next form:

$$
R_{M A, t}^{i}=\alpha^{i \mid s y s}+\delta^{i \mid s y s} \times R_{M A, t}^{s y s}+\varepsilon_{t}^{i \mid s y s}
$$

$\delta^{i \mid s y s}$ reflects the conditional dependence of bank i's return on the the system return, a large coefficient being associated with an enhanced systemic vulnerability. The estimations are run for each bank using a weekly frequency.

Running the Quantile Regression technique on Eq. (1) for the 1\% quantile of the returns' distribution we obtain the values of the regressors that will be used to calculate the Systemic vulnerability index (SV):

$$
\widehat{S V}_{q, t}^{i \mid s y s}=\hat{\alpha}_{q}^{i \mid s y s}+\hat{\delta}_{q}^{i \mid s y s} \times R_{M A, t}^{s y s}
$$

\subsection{Ordinary Least Squares estimations}

This impact of the degree of capital account openness at the country level on banks' systemic vulnerability is assessed using the following empirical model:

$$
\begin{aligned}
& \text { Systemic vulnerability }{ }_{i j t}=\beta_{0}+\beta_{1} \times \text { Financial openness } j, t-1_{1}+\Theta \times \text { Bank controlsij,t-1 }_{1}+ \\
& \psi \times \text { Macro controls }_{j, t-1}+\mu_{t}+\phi_{i}+\varepsilon_{i j, t}(3)
\end{aligned}
$$

The method used is OLS Fixed Effects with bank-level clustered standard errors. The dependent variable is the previously estimated Systemic vulnerability index of bank i from country $j$ in quarter $t$ (expressed in units of median \% loss of the banks' market assets within a quarter). Because SV index has weekly frequency we compute the median for each bank within each quarter in order to be matched with the other regressors.

All explanatory variables are lagged one period. Financial openness $s_{j, t-1}$ is represented by the Chinn-Ito index that measures country j's degree of capital account openness in the previous quarter. A detailed description of the bank and macro controls is given in the next section. All specifications include bank fixed effects, time fixed effects and an unreported constant. To alleviate the impact of large outliers variables are winsorized within the $1 \%$ and $99 \%$ percentiles. 


\section{Data}

To answer to the main research question we employ a number of bank-level and country-level variables. The bank level variables have quarterly frequency, while the macro characteristics present yearly frequency. Their definition and data source is provided in Table 1, while their descriptive statistics are given in Table 2.

\section{Table 1. Description of variables}

\begin{tabular}{|c|c|c|c|}
\hline Variable & Definition & Measure & Source \\
\hline \multicolumn{4}{|c|}{ Bank-quarter variables } \\
\hline $\begin{array}{l}\text { Systemic } \\
\text { vulnerability }\end{array}$ & $\begin{array}{l}\text { A measure that reflects the conditional dependence } \\
\text { of bank i's market assets returns ( } 1 \% \text { worst outcomes) } \\
\text { on the system's market assets return ( } 1 \% \text { worst } \\
\text { outcomes). The indicator is estimated using Quantile } \\
\text { Regression. Market assets are based on the book } \\
\text { value of total assets adjusted with the ratio of market } \\
\text { value of equity to book value of equity. }\end{array}$ & $\%$ & $\begin{array}{l}\text { Author's } \\
\text { calculations }{ }^{a} \text {, } \\
\text { Orbis }\end{array}$ \\
\hline $\begin{array}{l}\text { Asymmetric } \\
\text { systemic } \\
\text { vulnerability }\end{array}$ & $\begin{array}{l}\text { A measure that reflects the asymmetric conditional } \\
\text { dependence of bank i's market assets returns ( } 1 \% \\
\text { worst outcomes) on the system's market assets return } \\
\text { ( } 1 \% \text { worst outcomes). The indicator is estimated using } \\
\text { Quantile Regression and distinguishes among the } \\
\text { impact of positive and negative returns. Market assets } \\
\text { are based on the book value of total assets adjusted } \\
\text { with the ratio of market value of equity to book value } \\
\text { of equity. }\end{array}$ & $\%$ & $\begin{array}{l}\text { Author's } \\
\text { calculations }^{a} \text {, } \\
\text { Orbis }\end{array}$ \\
\hline Size & Logarithm of Total assets & $\begin{array}{l}\log (b i l . \\
\text { Eur) }\end{array}$ & Orbis \\
\hline Capital ratio & Equity to Total assets & $\%$ & Orbis \\
\hline Liquidity ratio & Liquid assets to Deposits and short term funding & $\%$ & Orbis \\
\hline $\begin{array}{l}\text { Loan loss reserve } \\
\text { ratio }\end{array}$ & Loan loss reserve to Gross loans & $\%$ & Orbis \\
\hline Solvency ratio & Net loans to Customer short term funding & $\%$ & Orbis \\
\hline ROAE & Return on average equity & $\%$ & Orbis \\
\hline \multicolumn{4}{|c|}{ Country-year variables } \\
\hline Chinn-Ito index & $\begin{array}{l}\text { Chinn-Ito Financial openness index measures a } \\
\text { country's degree of capital account openness. It is } \\
\text { based on the binary variables that tabulate the } \\
\text { restrictions on cross-border financial transactions } \\
\text { reported in the IMF's Annual Report on Exchange } \\
\text { Arrangements and Exchange Restrictions (AREAER) }\end{array}$ & units & $\begin{array}{l}\text { Chinn-Ito } \\
(2006)^{\mathrm{b}}\end{array}$ \\
\hline Concentration & $\begin{array}{l}\text { Assets of five largest banks as a share of total } \\
\text { commercial banking assets }\end{array}$ & $\%$ & World Bank \\
\hline Regulatory index & $\begin{array}{l}\text { A composite index that reflects how tight are the } \\
\text { regulatory and supervisory policies }\end{array}$ & units & $\begin{array}{l}\text { Barth et al. } \\
(2013)\end{array}$ \\
\hline GDP growth & Real GDP growth & $\%$ & World Bank \\
\hline Inflation & Change in CPI inflation, end of period & $\%$ & World Bank \\
\hline
\end{tabular}




\begin{tabular}{|c|c|c|c|}
\hline Variable & Definition & Measure & Source \\
\hline $\begin{array}{l}\text { Foreign ownership } \\
\text { dummy }\end{array}$ & $\begin{array}{l}\text { Dummy variable taking the value } 1 \text { when } 50 \% \text { or more } \\
\text { of banks' shares are owned by foreigners and } 0 \\
\text { otherwise }\end{array}$ & $0 / 1$ & Orbis \\
\hline $\begin{array}{l}\text { Vienna Initiative } \\
\text { dummy }\end{array}$ & $\begin{array}{l}\text { Dummy variable taking the value } 1 \text { if the bank i's parent } \\
\text { signed one or more Vienna Initiative commitment } \\
\text { letters and } 0 \text { otherwise }\end{array}$ & $0 / 1$ & EBRD \\
\hline $\begin{array}{l}\text { Capital regulatory } \\
\text { index dummy }\end{array}$ & $\begin{array}{l}\text { Dummy variable taking the value } 1 \text { if the median of } \\
\text { Capital regulatory index is above the median value for } \\
\text { entire sample of banks and } 0 \text { otherwise. Capital } \\
\text { regulatory index measures the amount of capital banks } \\
\text { must hold and the stringency of regulations on the } \\
\text { nature and source of regulatory capital. The index } \\
\text { takes values from } 0 \text { to } 10 \text {, higher values highlighting } \\
\text { tight regulations. }\end{array}$ & $0 / 1$ & $\begin{array}{l}\text { Barth et al. } \\
(2013), \\
\text { authors' } \\
\text { calculation }^{c}\end{array}$ \\
\hline $\begin{array}{l}\text { Private monitoring } \\
\text { index dummy }\end{array}$ & $\begin{array}{l}\text { Dummy variable taking the value } 1 \text { if the median of } \\
\text { Private monitoring index is above the median value for } \\
\text { entire sample of banks and } 0 \text { otherwise. Private } \\
\text { monitoring index reflects how much the regulatory and } \\
\text { supervisory actions encourage the monitoring of banks } \\
\text { by private investors. The index takes values from } 0 \text { to } \\
12 \text {, with higher values pointing towards a greater } \\
\text { regulatory empowerment of banks' private monitoring. }\end{array}$ & $0 / 1$ & $\begin{array}{l}\text { Barth et al. } \\
(2013), \\
\text { authors' } \\
\text { calculation }^{c}\end{array}$ \\
\hline
\end{tabular}

Note: ${ }^{a}$ Calculations are based on data from Orbis. ${ }^{b}$ The values of the index are based on Chinn-Ito (2006) and retrieved from http://web.pdx.edu/ ito/Chinn-Ito_website.htm. ${ }^{\circ}$ Calculations are based on data from Barth et al. (2013) retrieved from the World Bank Survey of Bank Regulation and Supervision (2003, 2007 and 2011).

As proxy for de jure financial openness we use the index developed by Chinn and Ito $(2006,2008)$ that measures a country's degree of capital account openness. It is based on the binary variables that tabulate the restrictions on cross-border financial transactions reported in the IMF's Annual Report on Exchange Arrangements and Exchange Restrictions (AREAER). Low restrictions on cross-border capital transactions are associated with a higher degree of financial openness. The average value of the measure across our sample is 0.77 , varying from -1.86 to 2.44 .

Table 2. Descriptive statistics

\begin{tabular}{lcccccccc}
\hline Variable & N & Mean & Std. & Min & p25 & p50 & p75 & Max \\
\hline Systemic vulnerability & 269 & 3.75 & 4.66 & -7.96 & 0.09 & 4.67 & 6.97 & 13.89 \\
Asymmetric systemic & 269 & 5.75 & 8.20 & -8.41 & 2.46 & 5.58 & 8.82 & 50.56 \\
vulnerability & 198 & 0.77 & 1.06 & -1.86 & 0.06 & 0.06 & 1.38 & 2.44 \\
Chinn-Ito index & 134 & 9.25 & 1.16 & 6.40 & 8.51 & 9.46 & 10.27 & 10.76 \\
Size & 134 & 11.17 & 3.23 & 3.93 & 8.79 & 11.11 & 13.83 & 19.11 \\
Capital ratio & 134 & 17.82 & 10.63 & 3.29 & 10.86 & 15.20 & 21.62 & 57.84 \\
Liquidity ratio & 114 & 5.88 & 2.94 & 1.75 & 3.63 & 4.97 & 7.87 & 15.15 \\
Loan loss reserve ratio & 134 & 84.23 & 20.71 & 44.76 & 74.47 & 82.88 & 91.80 & 195.18 \\
Solvency ratio & & & & & & & &
\end{tabular}




\begin{tabular}{lcccccccc}
\hline Variable & $\mathbf{N}$ & Mean & Std. & Min & p25 & p50 & p75 & Max \\
\hline ROAE & 134 & 9.31 & 8.92 & -17.35 & 4.80 & 9.97 & 14.82 & 42.98 \\
Concentration & 198 & 55.43 & 12.59 & 28.26 & 44.82 & 53.83 & 67.80 & 89.35 \\
Regulatory index & 269 & 0.63 & 0.14 & 0.46 & 0.46 & 0.59 & 0.69 & 0.90 \\
GDP growth & 198 & 5.05 & 14.63 & -50.00 & 0.00 & 8.51 & 15.25 & 29.41 \\
Inflation & 269 & 6.80 & 4.91 & -2.17 & 3.52 & 5.42 & 9.16 & 22.31 \\
Foreign ownership dummy & 269 & 0.72 & 0.45 & 0.00 & 0.00 & 1.00 & 1.00 & 1.00 \\
Vienna Initiative dummy & 269 & 0.71 & 0.45 & 0.00 & 0.00 & 1.00 & 1.00 & 1.00 \\
Capital regulatory index dummy & 269 & 5.65 & 2.23 & 3.00 & 3.00 & 6.00 & 8.00 & 10.00 \\
Private monitoring index dummy & 269 & 7.92 & 0.94 & 6.00 & 7.00 & 8.00 & 9.00 & 10.00 \\
\hline
\end{tabular}

Note: This table reports the summary statistics of the dependent and explanatory variables. Definitions of variables are provided in Table 1.

Analyzing the bank characteristics, Table 3 shows that on average banks from the CEE sample have a capital ratio of about $11.17 \%$, a liquidity ratio of $17.82 \%$, a loan loss reserve to gross loans of $5.88 \%$, a solvency ratio of 84.23 banks and a return on average equity ratio of $9.31 \%$. As for the banking sector attributes, the average concentration ratio is about $55 \%$, ranging from $28 \%$ to $89 \%$. The regulatory index varies from 0.46 to 0.90 , with an average of 0.64 across the sample. Table 3 reports the correlation among the dependent variables, financial openness index and bank controls employed in the empirical specification

Table 3. Correlation

\begin{tabular}{|c|c|c|c|c|c|c|c|c|c|}
\hline & $\begin{array}{c}\text { Systemic } \\
\text { vulnerability }\end{array}$ & $\begin{array}{c}\text { Asymmetric } \\
\text { SV }\end{array}$ & $\begin{array}{l}\text { Chinn-Ito } \\
\text { index }\end{array}$ & Size & $\begin{array}{c}\text { Capital } \\
\text { ratio }\end{array}$ & $\begin{array}{l}\text { Liquidity } \\
\text { ratio }\end{array}$ & $\begin{array}{l}\text { Loan loss } \\
\text { reserve } \\
\text { ratio }\end{array}$ & $\begin{array}{c}\text { Solvency } \\
\text { ratio }\end{array}$ & ROAE \\
\hline $\begin{array}{l}\text { Systemic } \\
\text { vulnerability }\end{array}$ & 1 & & & & & & & & \\
\hline Asymmetric SV & $0.7920^{*}$ & 1 & & & & & & & \\
\hline Chinn-Ito index & $-0.2125^{\star}$ & $-0.4172^{\star}$ & 1 & & & & & & \\
\hline Size & $0.5820^{*}$ & $0.6554^{*}$ & -0.1966 & 1 & & & & & \\
\hline Capital ratio & $0.2653^{*}$ & $0.2302^{*}$ & -0.128 & $0.4637^{*}$ & 1 & & & & \\
\hline Liquidity ratio & -0.0202 & 0.0135 & 0.2032 & 0.1852 & $0.4349^{*}$ & 1 & & & \\
\hline $\begin{array}{l}\text { Loan loss } \\
\text { reserve ratio }\end{array}$ & $-0.5052^{\star}$ & $-0.5041^{*}$ & -0.3122 & -0.2055 & 0.1478 & $0.3270^{\star}$ & 1 & & \\
\hline Solvency ratio & $-0.2489^{\star}$ & $-0.2456^{*}$ & 0.0367 & 0.0034 & -0.0366 & 0.0998 & 0.0003 & 1 & \\
\hline ROAE & $0.7663^{*}$ & $0.7644^{*}$ & 0.1309 & $0.6648^{\star}$ & $0.3836^{*}$ & 0.1912 & $-0.4857^{\star}$ & -0.1219 & 1 \\
\hline
\end{tabular}

Note: This table reports the correlation among the dependent variables, financial openness index and bank controls employed in the empirical specification. Their definition is provided in Table $1 .{ }^{*}$ denotes significance at $1 \%$. 


\section{Results}

\subsection{Main results}

A univariate analysis of the nexus between the restrictions on cross-border capital transactions and systemic vulnerability of banks is provided in Table 4 . The sample is split among banks form countries with a high degree of capital account openness (when the Chinn-Ito index is above the median value for the entire sample, Panel A) and banks form countries with a low degree of capital account openness (when the Chinn-Ito index is below the median value for the entire sample, Panel B). Panel $\mathrm{C}$ provides the difference in means analysis and shows a greater systemic vulnerability (that is statistically significant) for banks from countries with less stringent restrictions on cross-border capital activities. The average quarterly median exposure to systemic events during the analyzed period is about 5.57 percent loss for the high financial openness subsample, while for the low financial openness subsample the loss is about 2.32 percent.

Table 4. Univariate analysis

\begin{tabular}{l|cc|cc|cc}
\hline & \multicolumn{2}{|c|}{$\begin{array}{c}\text { A. High financial openness } \\
\text { sample }\end{array}$} & $\begin{array}{c}\text { B. Low financial openness } \\
\text { sample }\end{array}$ & \multicolumn{2}{c}{$\begin{array}{c}\text { C. Difference in means } \\
\text { analysis: High versus low } \\
\text { financial openness index }\end{array}$} \\
\hline Statistics & $\begin{array}{c}\text { Systemic } \\
\text { vulnerability }\end{array}$ & $\begin{array}{c}\text { Asymmetric } \\
\text { SV }\end{array}$ & $\begin{array}{c}\text { Systemic } \\
\text { vulnerability }\end{array}$ & $\begin{array}{c}\text { Asymmetric } \\
\text { SV }\end{array}$ & $\begin{array}{c}\text { Systemic } \\
\text { vulnerability }\end{array}$ & $\begin{array}{c}\text { Asymmetric } \\
\text { SV }\end{array}$ \\
N & 102 & 102 & 96 & 96 & & $5.940 * * *$ \\
Mean & 5.572 & 9.187 & 2.317 & 3.247 & $3.255 * * *$ & \\
Std. & 4.618 & 10.107 & 4.597 & 5.992 & \\
Min & -6.146 & -5.952 & -7.963 & -8.405 & \\
p25 & 4.614 & 5.010 & -0.641 & -2.298 & \\
p50 & 6.521 & 7.506 & 2.802 & 4.061 & \\
p75 & 8.316 & 10.969 & 5.167 & 7.856 & \\
Max & 13.886 & 50.563 & 11.885 & 15.413 & \\
\hline
\end{tabular}

Note: This table provides the difference in means analysis of the dependent variables Systemic vulnerability and Asymmetric systemic vulnerability during 2005-2012 for the sample of banks from CEE countries with a high financial openness index (Panel A) and a low financial openness index (Panel B). Panel $\mathrm{C}$ exhibits the difference in means among the two sub-samples. The systemic vulnerability indices are determined using the Quantile Regression methodology and are expressed in units of median \% loss of the banks' market assets within a quarter. Higher values of the indices reflect greater vulnerability to systemic events. Table 1 provides detailed definitions of the measures.

Table 5 depicts the results of the multivariate analysis. We start with a specification that accounts for bank characteristics, as well as bank fixed effects and time fixed effects (model 1). The output highlights a positive impact of a higher degree of capital account openness on banks' systemic vulnerability that is strongly statistically significant. A one standard deviation increase in the Chinn-Ito index generates about 25 percent standard deviation increase in the systemic vulnerability index. In models (2) and (3) we add the banking market concentration and the overall regulatory index to account for heterogeneity among different banking sectors. In models (4) and (5) we add additional macroeconomic controls, GDP growth and inflation. All specifications confirm the robustness of our initial findings. It is worth mentioning that controlling for more banking market and macroeconomic characteristics improve the economic significance of the output. A one standard deviation shock to the Chinn-Ito index is linked with a 42 percent standard deviation change in the systemic vulnerability index (model 5). 
Table 5. Main results: systemic vulnerability and financial openness

\begin{tabular}{|c|c|c|c|c|c|}
\hline VARIABLES & $\begin{array}{c}(1) \\
\text { Systemic } \\
\text { vulnerability }\end{array}$ & $\begin{array}{c}(2) \\
\text { Systemic } \\
\text { vulnerability }\end{array}$ & $\begin{array}{c}(3) \\
\text { Systemic } \\
\text { vulnerability }\end{array}$ & $\begin{array}{c}(4) \\
\text { Systemic } \\
\text { vulnerability }\end{array}$ & $\begin{array}{c}(5) \\
\text { Systemic } \\
\text { vulnerability }\end{array}$ \\
\hline \multicolumn{6}{|l|}{ Financial openness } \\
\hline Chinn-Ito index & $\begin{array}{c}1.111^{\star * \star} \\
(0.22)\end{array}$ & $\begin{array}{c}1.055^{\star \star * \star} \\
(0.34)\end{array}$ & $\begin{array}{c}1.062^{* * *} \\
(0.34)\end{array}$ & $\begin{array}{c}1.892^{* * *} \\
(0.50)\end{array}$ & $\begin{array}{c}1.866^{* * *} \\
(0.48)\end{array}$ \\
\hline \multicolumn{6}{|l|}{ Bank controls } \\
\hline Size & $\begin{array}{l}0.045 \\
(0.47)\end{array}$ & $\begin{array}{l}0.042 \\
(0.46)\end{array}$ & $\begin{array}{l}0.007 \\
(0.47)\end{array}$ & $\begin{array}{l}0.111 \\
(0.68)\end{array}$ & $\begin{array}{l}0.173 \\
(0.63)\end{array}$ \\
\hline Capital ratio & $\begin{array}{c}-0.209^{* * *} \\
(0.06)\end{array}$ & $\begin{array}{c}-0.210^{\star \star \star *} \\
(0.06)\end{array}$ & $\begin{array}{c}-0.220^{\star * *} \\
(0.06)\end{array}$ & $\begin{array}{c}-0.262^{\star * *} \\
(0.07)\end{array}$ & $\begin{array}{c}-0.261^{\star \star *} \\
(0.07)\end{array}$ \\
\hline Liquidity ratio & $\begin{array}{l}0.001 \\
(0.02)\end{array}$ & $\begin{array}{l}0.001 \\
(0.02)\end{array}$ & $\begin{array}{l}0.001 \\
(0.02)\end{array}$ & $\begin{array}{l}0.004 \\
(0.02)\end{array}$ & $\begin{array}{l}0.003 \\
(0.02)\end{array}$ \\
\hline Loan loss reserve & $\begin{array}{l}0.054 \\
(0.04)\end{array}$ & $\begin{array}{l}0.046 \\
(0.05)\end{array}$ & $\begin{array}{l}0.047 \\
(0.05)\end{array}$ & $\begin{array}{l}0.063 \\
(0.06)\end{array}$ & $\begin{array}{l}0.060 \\
(0.06)\end{array}$ \\
\hline Solvency ratio & $\begin{array}{l}0.010 \\
(0.01)\end{array}$ & $\begin{array}{l}0.010 \\
(0.01)\end{array}$ & $\begin{array}{l}0.010 \\
(0.01)\end{array}$ & $\begin{array}{l}0.009 \\
(0.01)\end{array}$ & $\begin{array}{l}0.009 \\
(0.01)\end{array}$ \\
\hline ROAE & $\begin{array}{c}0.027^{\star * *} \\
(0.01)\end{array}$ & $\begin{array}{c}0.026^{\star \star *} \\
(0.01)\end{array}$ & $\begin{array}{c}0.026^{\star * *} \\
(0.01)\end{array}$ & $\begin{array}{c}0.027^{\star \star *} \\
(0.01)\end{array}$ & $\begin{array}{c}0.027^{* * *} \\
(0.01)\end{array}$ \\
\hline Macro controls & & & & & \\
\hline Concentration & & $\begin{array}{l}0.007 \\
(0.04)\end{array}$ & $\begin{array}{l}0.024 \\
(0.03)\end{array}$ & $\begin{array}{l}0.026 \\
(0.04)\end{array}$ & $\begin{array}{l}0.024 \\
(0.04)\end{array}$ \\
\hline Regulatory index & & & $\begin{array}{l}1.138 \\
(0.80)\end{array}$ & $\begin{array}{l}1.229 \\
(0.77)\end{array}$ & $\begin{array}{l}1.069 \\
(0.81)\end{array}$ \\
\hline GDP growth & & & & $\begin{array}{c}0.018^{\star *} \\
(0.01)\end{array}$ & $\begin{array}{c}0.020^{* *} \\
(0.01)\end{array}$ \\
\hline Inflation & & & & & $\begin{array}{l}-0.016 \\
(0.02)\end{array}$ \\
\hline Observations & 292 & 292 & 292 & 269 & 269 \\
\hline R-squared & 0.391 & 0.391 & 0.395 & 0.430 & 0.431 \\
\hline Number of banks & 25 & 25 & 25 & 25 & 25 \\
\hline Number of countries & 10 & 10 & 10 & 10 & 10 \\
\hline Time FE & YES & YES & YES & YES & YES \\
\hline Country FE & YES & YES & YES & YES & YES \\
\hline Cluster & Bank & Bank & Bank & Bank & Bank \\
\hline
\end{tabular}

Note: This table reports the estimation results of the following empirical model:

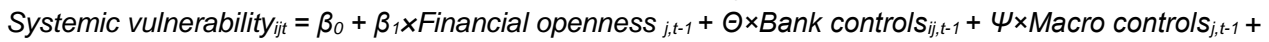
$\mu_{t}+\phi_{i}+\varepsilon_{i j, t}$

The method used is OLS Fixed Effects. The sample includes 25 banks from 10 countries of Central and Eastern Europe analyzed during 2005-2012. The dependent variable is Systemic vulnerability of bank i's from country j in quarter t (expressed in units of median \% loss of the banks' market assets within a quarter). Explanatory variables are lagged one period. All specifications include bank fixed effects, time fixed effects and an unreported constant. Variables are winsorized within the $1 \%$ and $99 \%$ percentiles, their definition being provided in Table 1. Standard errors clustered at bank level are reported in brackets. ${ }^{*},{ }^{* \star}$ and ${ }^{* \star \star}$ denote significance levels of $10 \%$, $5 \%$ and $1 \%$. 


\subsection{Robustness}

These section asses the robustness of the dependant variable. In what follows we replace the SV index with an asymmetric correction considering that negative returns of the system's market assets could have a greater impact in absolute terms on banks' vulnerability.

The dependence of each bank's market assets returns on the system's returns is expressed using the next form:

$$
\begin{aligned}
R_{M A, t}^{i}=\alpha^{i \mid s y s}+ & \delta^{i \mid \text { sys }(-)} \times R_{\text {Market Assets }, t}^{\text {sys }} \times I_{\left(R_{\text {Market Assets }, t}^{\text {sys }}<0\right)} \\
& +\delta^{i \mid \text { sys }(+)} \times R_{\text {Market Assets }, t}^{\text {sys }} \times I_{\left(R_{\text {Market Assets }, t}^{\text {sys }} \geq 0\right)}+\varepsilon_{t}^{i \mid \text { asys }}
\end{aligned}
$$

$\delta^{i \mid s y s(-)}$ and $\delta^{i \mid s y s(+)}$ reflect the conditional dependence of bank i's market assets returns on the system's market assets returns when they are negative $\left(I_{\cdot<0}\right)$ and, respectively, positive $\left(I_{: \geq 0}\right)$. Large coefficients are associated with an enhanced systemic vulnerability. The estimations are run for each bank using a weekly frequency.

Running the Quantile Regression technique on Eq. (4) for the 1\% quantile of the returns' distribution we obtain the values of the regressors that will be used to calculate the Asymmetric systemic vulnerability index (ASV):

$$
\begin{aligned}
\widehat{A S V_{q, t}^{i \mid s y s}=\hat{\alpha}_{q}^{i \mid s y s}} & +\hat{\delta}_{q}^{i \mid \operatorname{sys}(-)} \times R_{\text {Market Assets }, t}^{\text {sys }} \times I_{\left(R_{\text {Market Assets }, t}^{\text {sys }}<0\right)} \\
& +\hat{\delta}_{q}^{i \mid \text { sys }(+)} \times R_{\text {Market Assets }, t}^{\text {sys }} \times I_{\left(R_{\text {Market Assets }, t}^{\text {sys }} \geq 0\right)}
\end{aligned}
$$

The results shown in Table 6 validate the positive impact of a higher degree of capital account openness on banks' systemic vulnerability, the economic impact being greater. A one standard deviation shock to the Chinn-Ito index produces a 50

\begin{tabular}{|c|c|c|c|c|c|}
\hline VARIABLES & $\begin{array}{c}(1) \\
\text { Asymmetric } \\
\text { SV }\end{array}$ & $\begin{array}{c}(2) \\
\text { Asymmetric } \\
\text { SV }\end{array}$ & $\begin{array}{c}(3) \\
\text { Asymmetric } \\
\text { SV }\end{array}$ & $\begin{array}{c}(4) \\
\text { Asymmetric } \\
\text { SV }\end{array}$ & $\begin{array}{c}(5) \\
\text { Asymmetric } \\
\text { SV }\end{array}$ \\
\hline \multicolumn{6}{|l|}{ Financial openness } \\
\hline Chinn-Ito index & $\begin{array}{c}2.008^{* * *} \\
(0.50)\end{array}$ & $\begin{array}{c}1.591^{\star * *} \\
(0.43)\end{array}$ & $\begin{array}{c}1.600 * \star * \\
(0.43)\end{array}$ & $\begin{array}{c}3.942^{\star \star *} \\
(1.14)\end{array}$ & $\begin{array}{c}3.898^{\star \star *} \\
(1.11)\end{array}$ \\
\hline Bank controls & & & & & \\
\hline Size & $\begin{array}{l}0.267 \\
(1.14)\end{array}$ & $\begin{array}{l}0.248 \\
(1.09)\end{array}$ & $\begin{array}{l}0.200 \\
(1.07)\end{array}$ & $\begin{array}{l}-0.277 \\
(1.05)\end{array}$ & $\begin{array}{l}-0.174 \\
(0.94)\end{array}$ \\
\hline Capital ratio & $\begin{array}{c}-0.489^{\star \star} \\
(0.23)\end{array}$ & $\begin{array}{c}-0.504^{\star \star} \\
(0.23)\end{array}$ & $\begin{array}{c}-0.517^{\star *} \\
(0.24)\end{array}$ & $\begin{array}{c}-0.595^{\star \star \star} \\
(0.21)\end{array}$ & $\begin{array}{c}-0.593^{\star \star \star} \\
(0.21)\end{array}$ \\
\hline Liquidity ratio & $\begin{array}{l}-0.006 \\
(0.02)\end{array}$ & $\begin{array}{l}-0.006 \\
(0.02)\end{array}$ & $\begin{array}{l}-0.007 \\
(0.02)\end{array}$ & $\begin{array}{l}0.009 \\
(0.02)\end{array}$ & $\begin{array}{l}0.009 \\
(0.02)\end{array}$ \\
\hline Loan loss reserve & $\begin{array}{l}-0.051 \\
(0.05)\end{array}$ & $\begin{array}{l}-0.104 \\
(0.08)\end{array}$ & $\begin{array}{l}-0.103 \\
(0.08) \\
\end{array}$ & $\begin{array}{l}-0.215 \\
(0.13)\end{array}$ & $\begin{array}{c}-0.220^{*} \\
(0.13)\end{array}$ \\
\hline
\end{tabular}
percent standard deviation change in the systemic vulnerability index when considering the asymmetric correction (model 5).

Table 6. Robustness check using a different proxy for systemic vulnerability 


\begin{tabular}{|c|c|c|c|c|c|}
\hline VARIABLES & $\begin{array}{c}(1) \\
\text { Asymmetric } \\
\text { SV }\end{array}$ & $\begin{array}{c}(2) \\
\text { Asymmetric } \\
\text { SV }\end{array}$ & $\begin{array}{c}(3) \\
\text { Asymmetric } \\
\text { SV }\end{array}$ & $\begin{array}{c}(4) \\
\text { Asymmetric } \\
\text { SV }\end{array}$ & $\begin{array}{c}(5) \\
\text { Asymmetric } \\
\text { SV }\end{array}$ \\
\hline \multirow[t]{2}{*}{ Solvency ratio } & 0.014 & 0.017 & 0.017 & 0.010 & 0.010 \\
\hline & $(0.01)$ & $(0.01)$ & $(0.01)$ & $(0.01)$ & $(0.01)$ \\
\hline \multirow[t]{2}{*}{ ROAE } & $0.021^{\star \star}$ & $0.019^{*}$ & $0.018^{*}$ & 0.014 & 0.014 \\
\hline & $(0.01)$ & $(0.01)$ & $(0.01)$ & $(0.01)$ & $(0.01)$ \\
\hline \multicolumn{6}{|l|}{ Macro controls } \\
\hline \multirow[t]{2}{*}{ Concentration } & & 0.054 & 0.076 & 0.065 & 0.063 \\
\hline & & $(0.05)$ & $(0.06)$ & $(0.06)$ & $(0.06)$ \\
\hline \multirow[t]{2}{*}{ Regulatory index } & & & 1.546 & 0.144 & -0.121 \\
\hline & & & $(1.77)$ & $(1.50)$ & (1.61) \\
\hline \multirow[t]{2}{*}{ GDP growth } & & & & -0.010 & -0.007 \\
\hline & & & & $(0.02)$ & $(0.02)$ \\
\hline \multirow[t]{2}{*}{ Inflation } & & & & & -0.027 \\
\hline & & & & & $(0.05)$ \\
\hline Observations & 292 & 292 & 292 & 269 & 269 \\
\hline R-squared & 0.322 & 0.327 & 0.328 & 0.420 & 0.420 \\
\hline Number of banks & 25 & 25 & 25 & 25 & 25 \\
\hline Number of countries & 10 & 10 & 10 & 10 & 10 \\
\hline Time FE & YES & YES & YES & YES & YES \\
\hline Country FE & YES & YES & YES & YES & YES \\
\hline Cluster & Bank & Bank & Bank & Bank & Bank \\
\hline
\end{tabular}

Note: This table reports the estimation results of the following empirical model:

$$
\begin{aligned}
\text { Asymmetric systemic vulnerability }{ }_{i j t} & =\beta_{0}+\beta_{1} \times \text { Financial openness }_{j, t-1}+\Theta \times \text { Bank controls }_{i j, t-1}+ \\
& \Psi \times \text { Macro controls }_{j, t-1}+\mu_{t}+\phi_{i}+\varepsilon_{i j, t}
\end{aligned}
$$

The method used is OLS Fixed Effects. The sample includes 25 banks from 10 countries of Central and Eastern Europe analyzed during 2005-2012. The dependent variable is Asymmetric systemic vulnerability of bank i's from country $\mathrm{j}$ in quarter $\mathrm{t}$ (expressed in units of median \% loss of the banks' market assets within a quarter). Explanatory variables are lagged one period. All specifications include bank fixed effects, time fixed effects and an unreported constant. Variables are winsorized within the $1 \%$ and $99 \%$ percentiles, their definition being provided in Table 1 . Standard errors clustered at bank level are reported in brackets. ${ }^{*}$, ${ }^{*}$ and *** denote significance levels of $10 \%, 5 \%$ and $1 \%$.

\subsection{Further extensions}

In this section we explore the effects of ownership and regulatory policies on the relationship between financial openness and systemic vulnerability. Our intuition is that the positive impact of capital account openness on banks' vulnerability could be lower for foreign owned banks and for financial institutions from countries with strong monitoring regulations.

To exploit the effects of ownership we start by constructing a dummy variable that takes the value 1 if $50 \%$ or more of banks' shares are owned by foreigners and 0 otherwise. The following empirical model is estimated using OLS Fixed Effects:

$$
\begin{aligned}
& \text { Systemic vulnerability }{ }_{j i t}=\beta_{0}+\beta_{1} \times \text { Financial openness } j_{t,-1}+\beta_{2} \times \text { Financial openness } j_{j,-1} \times \\
& \text { Foreign ownership dummy } y_{i, t-1}+\Theta \times B \text { ank controls } s_{j, t-1}+\psi \times{ } \text { Macro controls } s_{j, t-1}+ \\
& \mu_{t}+\phi_{i}+\varepsilon_{i j, t}
\end{aligned}
$$


The empirical output presented in Table 7 indicates that the interaction between the Chinn-Ito index and foreign ownership dummy is negative and statistically significant at $5 \%$. This suggests that the harmful effect of less stringent restrictions related to cross-border capital transactions on banks' vulnerability is lower for foreign owned banks.

Table 7. Systemic vulnerability, financial openness and foreign ownership

\begin{tabular}{|c|c|c|c|c|c|}
\hline VARIABLES & $\begin{array}{c}(1) \\
\text { Systemic } \\
\text { vulnerability }\end{array}$ & $\begin{array}{c}(2) \\
\text { Systemic } \\
\text { vulnerability }\end{array}$ & $\begin{array}{c}(3) \\
\text { Systemic } \\
\text { vulnerability }\end{array}$ & $\begin{array}{c}(4) \\
\text { Systemic } \\
\text { vulnerability }\end{array}$ & $\begin{array}{c}5) \\
\text { Systemic } \\
\text { vulnerability }\end{array}$ \\
\hline \multicolumn{6}{|l|}{ Financial openness } \\
\hline Chinn-Ito index & $\begin{array}{c}1.826^{\star * \star} \\
(0.59)\end{array}$ & $\begin{array}{c}1.821^{* * *} \\
(0.55)\end{array}$ & $\begin{array}{c}1.759^{* * *} \\
(0.53)\end{array}$ & $\begin{array}{c}2.625^{\star \star *} \\
(0.75)\end{array}$ & $\begin{array}{c}2.637^{\star \star *} \\
(0.73)\end{array}$ \\
\hline $\begin{array}{l}\text { Chinn-Ito index } \times \text { Foreign } \\
\text { ownership dummy }\end{array}$ & $\begin{array}{l}-0.482^{*} \\
(0.24)\end{array}$ & $\begin{array}{c}-0.545^{\star *} \\
(0.21)\end{array}$ & $\begin{array}{c}-0.515^{\star \star} \\
(0.20)\end{array}$ & $\begin{array}{l}-0.564^{*} \\
(0.28)\end{array}$ & $\begin{array}{c}-0.574^{\star *} \\
(0.28)\end{array}$ \\
\hline Foreign ownership dummy & $\begin{array}{l}-0.501^{*} \\
(0.25)\end{array}$ & $\begin{array}{c}-0.507^{* *} \\
(0.23)\end{array}$ & $\begin{array}{l}-0.576^{\star *} \\
(0.23)\end{array}$ & $\begin{array}{l}-0.494^{*} \\
(0.27)\end{array}$ & $\begin{array}{l}-0.450 \\
(0.29)\end{array}$ \\
\hline Bank controls & & & & & \\
\hline Size & $\begin{array}{l}0.097 \\
(0.44)\end{array}$ & $\begin{array}{l}0.092 \\
(0.41)\end{array}$ & $\begin{array}{l}0.064 \\
(0.42)\end{array}$ & $\begin{array}{l}0.231 \\
(0.60)\end{array}$ & $\begin{array}{l}0.266 \\
(0.56)\end{array}$ \\
\hline Capital ratio & $\begin{array}{c}-0.210^{\star * *} \\
(0.06)\end{array}$ & $\begin{array}{c}-0.215^{\star \star \star} \\
(0.06)\end{array}$ & $\begin{array}{c}-0.223^{\star \star \star *} \\
(0.06)\end{array}$ & $\begin{array}{c}-0.267^{* * *} \\
(0.07)\end{array}$ & $\begin{array}{c}-0.267^{\star \star \star} \\
(0.07)\end{array}$ \\
\hline Liquidity ratio & $\begin{array}{l}0.002 \\
(0.02)\end{array}$ & $\begin{array}{l}0.002 \\
(0.02)\end{array}$ & $\begin{array}{l}0.002 \\
(0.02)\end{array}$ & $\begin{array}{l}0.005 \\
(0.02)\end{array}$ & $\begin{array}{l}0.005 \\
(0.02)\end{array}$ \\
\hline Loan loss reserve ratio & $\begin{array}{l}0.035 \\
(0.04)\end{array}$ & $\begin{array}{l}0.017 \\
(0.05)\end{array}$ & $\begin{array}{l}0.020 \\
(0.05)\end{array}$ & $\begin{array}{l}0.031 \\
(0.06)\end{array}$ & $\begin{array}{l}0.028 \\
(0.06)\end{array}$ \\
\hline Solvency ratio & $\begin{array}{l}0.010 \\
(0.01)\end{array}$ & $\begin{array}{l}0.010 \\
(0.01)\end{array}$ & $\begin{array}{l}0.010 \\
(0.01)\end{array}$ & $\begin{array}{l}0.009 \\
(0.01)\end{array}$ & $\begin{array}{l}0.009 \\
(0.01)\end{array}$ \\
\hline ROAE & $\begin{array}{l}0.025^{\star \star \star} \\
(0.01)\end{array}$ & $\begin{array}{c}0.025^{\star \star \star} \\
(0.01)\end{array}$ & $\begin{array}{c}0.024^{* * *} \\
(0.01)\end{array}$ & $\begin{array}{c}0.025^{\star \star \star} \\
(0.01)\end{array}$ & $\begin{array}{c}0.025^{\star \star \star} \\
(0.01)\end{array}$ \\
\hline Macro controls & & & & & \\
\hline Concentration & & $\begin{array}{l}0.015 \\
(0.04)\end{array}$ & $\begin{array}{l}0.032 \\
(0.04)\end{array}$ & $\begin{array}{l}0.035 \\
(0.04)\end{array}$ & $\begin{array}{l}0.034 \\
(0.04)\end{array}$ \\
\hline Regulatory index & & & $\begin{array}{l}1.184 \\
(0.79)\end{array}$ & $\begin{array}{l}1.316 \\
(0.77)\end{array}$ & $\begin{array}{l}1.200 \\
(0.81)\end{array}$ \\
\hline GDP growth & & & & $\begin{array}{l}0.022^{* *} \\
(0.01)\end{array}$ & $\begin{array}{l}0.023^{* *} \\
(0.01)\end{array}$ \\
\hline Inflation & & & & & $\begin{array}{l}-0.011 \\
(0.02)\end{array}$ \\
\hline Observations & 292 & 292 & 292 & 269 & 269 \\
\hline R-squared & 0.399 & 0.400 & 0.404 & 0.439 & 0.439 \\
\hline Number of banks & 25 & 25 & 25 & 25 & 25 \\
\hline Number of countries & 10 & 10 & 10 & 10 & 10 \\
\hline
\end{tabular}




\begin{tabular}{lccccc}
\hline & $(1)$ & $(2)$ & $(3)$ & $(4)$ & $(5)$ \\
Vystemic & $\begin{array}{c}\text { Systemic } \\
\text { vulnerability }\end{array}$ & $\begin{array}{c}\text { Systemic } \\
\text { vulnerability }\end{array}$ & $\begin{array}{c}\text { Systemic } \\
\text { vulnerability }\end{array}$ & $\begin{array}{c}\text { Systemic } \\
\text { vulnerability }\end{array}$ & vulnerability \\
\hline Time FE & YES & YES & YES & YES & YES \\
Country FE & YES & YES & YES & YES & YES \\
Cluster & Bank & Bank & Bank & Bank & Bank \\
\hline
\end{tabular}

Note: This table reports the estimation results of the following empirical model:

Systemic vulnerability ${ }_{j i t}=\beta_{0}+\beta_{1} \times$ Financial openness $j_{j, t-1}+\beta_{2} \times$ Financial openness $_{j, t-1} \times$ Foreign

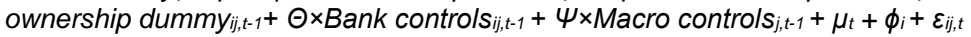

The method used is OLS Fixed Effects. The sample includes 25 banks from 10 countries of Central and Eastern Europe analyzed during 2005-2012. The dependent variable is Systemic vulnerability of bank i's from country $\mathrm{j}$ in quarter $\mathrm{t}$ (expressed in units of median \% loss of the banks' market assets within a quarter). Explanatory variables are lagged one period. All specifications include bank fixed effects, time fixed effects and an unreported constant. Variables are winsorized within the $1 \%$ and $99 \%$ percentiles, their definition being provided in Table 1. Standard errors clustered at bank level are reported in brackets. ${ }^{*}$ ** and ${ }^{* \star *}$ denote significance levels of $10 \%, 5 \%$ and $1 \%$.

Next, we assess the effects of Vienna Initiative commitments on the relationship between financial openness and systemic vulnerability. Within the Vienna Initiative a number of banks from Western Europe with subsidiaries in CEE region signed commitments letters with the aim to maintain exposures in CEE banking system and support their subsidiaries during the financial crisis period. The Chinn-Ito index is interacted with a dummy variable that takes the value 1 if the banks' parent signed one or more Vienna Initiative commitment letters and 0 otherwise. The following empirical model is estimated using OLS Fixed Effects:

$$
\begin{aligned}
& \text { Systemic vulnerability }{ }_{j t}=\beta_{0}+\beta_{1} \times \text { Financial openness } j, t-1+\beta_{2} \times \text { Financial openness } j, t-1 \times \times
\end{aligned}
$$

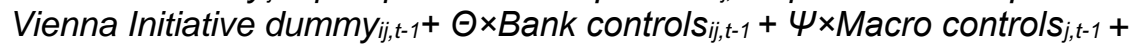

$$
\begin{aligned}
& \mu_{t}+\phi_{i}+\varepsilon_{i j, t}
\end{aligned}
$$

Table 8. Systemic vulnerability, financial openness and Vienna Initiative

(1)

Systemic

\section{VARIABLES}

(2)

(3)

(4)

(5) vulnerability vulnerability vulnerability vulnerability vulnerability

Financial openness

Chinn-Ito index

$$
1.640 \text { *** }
$$

Chinn-Ito index $\times$ Vienna Initiative dummy

Vienna Initiative dummy

Bank controls

$\begin{array}{ccccc}-0.498^{\star} & -0.513^{\star} & -0.525^{\star *} & -0.509^{\star *} & -0.506^{\star *} \\ (0.25) & (0.26) & (0.25) & (0.24) & (0.23) \\ 0.145 & 0.137 & 0.149 & 0.118 & 0.119 \\ (0.32) & (0.34) & (0.34) & (0.39) & (0.39)\end{array}$

Size 
(1)

(2)

(3)

(4)

(5)

VARIABLES

Systemic Systemic Systemic Systemic Systemic vulnerability vulnerability vulnerability vulnerability vulnerability

Capital ratio

$-0.205^{\star \star *}$

$-0.204^{* * *}$

$-0.214^{\star \star *}$

$-0.254^{\star \star \star}$

$-0.254^{\star \star \star}$

(0.06)

$(0.06)$

$(0.06)$

$(0.08)$

$(0.08)$

Liquidity ratio

0.001

0.001

0.001

0.002

0.002

$(0.01)$

$(0.01)$

$(0.01)$

(0.02)

$(0.02)$

Loan loss reserve ratio

(0.05)

0.093

0.095

0.112

0.111

0.011

(0.06)

$(0.06)$

(0.07)

$(0.07)$

Solvency ratio

$(0.01)$

0.010

0.010

0.010

0.010

$0.028^{\star \star *}$

(0.01)

(0.01)

(0.01)

(0.01)

ROAE

(0.01)

$0.028^{*}$
$(0.01)$

$0.028^{\star \star \star}$

$0.029^{\star \star *}$

$0.029^{\star \star \star}$

Macro controls

Concentration

-0.007
$(0.04)$

(0.01)

(0.01)

(0.01)

Regulatory index

\subsection{1}

0.016

0.016

1.230

(0.04)

(0.04)

(0.75)

$1.447^{*}$

$1.416^{\star}$

GDP growth

(0.77)

$0.016^{*}$

$0.017^{*}$

(0.01)

$(0.01)$

$-0.003$

(0.02)

Observations

R-squared

Number of banks

$\begin{array}{cc}292 & 292 \\ 0.408 & 0.408 \\ 25 & 25 \\ 10 & 10 \\ \text { YES } & \text { YES } \\ \text { YES } & \text { YES } \\ \text { Bank } & \text { Bank }\end{array}$

292
0.413
25
10
YES
YES
Bank

269

269

.408

0.445

0.445

Number of countries

Time FE

Country FE

Bank

Bank

Bank

$25 \quad 25$

$10 \quad 10$

YES YES

YES YES

Bank Bank

Note: This table reports the estimation results of the following empirical model:

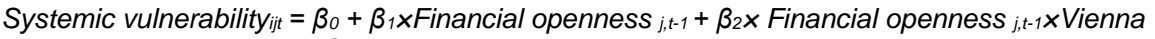
Innitiative $e_{i, t-1-1}+\Theta \times$ Bank controlsij,t-1 $+\psi \times$ Macro controls $_{j, t-1}+\mu_{t}+\phi_{i}+\varepsilon_{i j, t}$

The method used is OLS Fixed Effects. The sample includes 25 banks from 10 countries of Central and Eastern Europe analyzed during 2005-2012. The dependent variable is Systemic vulnerability of bank i's from country $\mathrm{j}$ in quarter $\mathrm{t}$ (expressed in units of median \% loss of the banks' market assets within a quarter). Explanatory variables are lagged one period. All specifications include bank fixed effects, time fixed effects and an unreported constant. Variables are winsorized within the $1 \%$ and $99 \%$ percentiles, their definition being provided in Table 1 . Standard errors clustered at bank level are reported in

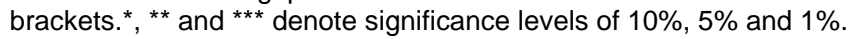

Table 8 shows that the interaction between the Chinn-Ito index and Vienna Initiative dummy is negative and statistically significant. This suggests that the positive impact of a higher degree of capital accounts openness on banks' vulnerability to systemic events is lower for banks whose bank holding company signed one or more Vienna Initiative commitment letters during the financial crisis.

Further, we exploit if the nexus among the degree of financial openness and systemic vulnerability is heterogeneous across the banking systems' capital regulatory framework. Capital regulatory index developed by Barth et al. (2008) measures the 
amount of capital banks must hold and the stringency of regulations on the nature and source of regulatory capital. The index takes values from 0 to 10, higher values highlighting tight regulations. We consider the interaction of Chinn-Ito index with a dummy variable taking the value 1 if the median of Capital regulatory index is above the median value for entire sample of banks and 0 otherwise, as follows:

$$
\begin{gathered}
\text { Systemic vulnerability }{ }_{i j t}=\beta_{0}+\beta_{1} \times \text { Financial openness }_{j, t-1}+\beta_{2} \times \text { Financial openness } j, t-1 \times \times \\
\text { Capital regulatory index } x_{j, t-1}+\Theta \times \text { Bank controls }_{i j, t-1}+\Psi \times \text { Macro controls }_{j, t-1}+ \\
\mu_{t}+\phi_{i}+\varepsilon_{i j, t}
\end{gathered}
$$

The results presented in Table 9 shows that the interaction between the ChinnIto index and capital regulatory dummy is positive and highly significant. This suggests that the positive impact of a higher degree of capital accounts openness on banks' vulnerability to systemic events is higher in countries with tighter regulations on the

\begin{tabular}{|c|c|c|c|c|c|}
\hline VARIABLES & $\begin{array}{c}(1) \\
\text { Systemic } \\
\text { vulnerability }\end{array}$ & $\begin{array}{c}(2) \\
\text { Systemic } \\
\text { vulnerability }\end{array}$ & $\begin{array}{c}(3) \\
\text { Systemic } \\
\text { vulnerability }\end{array}$ & $\begin{array}{c}(4) \\
\text { Systemic } \\
\text { vulnerability }\end{array}$ & $\begin{array}{c}(5) \\
\text { Systemic } \\
\text { vulnerability }\end{array}$ \\
\hline \multicolumn{6}{|l|}{ Financial openness } \\
\hline Chinn-Ito index & $\begin{array}{c}1.283^{\star \star \star} \\
(0.32)\end{array}$ & $\begin{array}{c}1.235^{\star \star \star} \\
(0.34)\end{array}$ & $\begin{array}{c}1.153^{\star \star \star} \\
(0.39)\end{array}$ & $\begin{array}{c}1.932^{\star \star \star} \\
(0.50)\end{array}$ & $\begin{array}{c}1.944^{* \star \star} \\
(0.48)\end{array}$ \\
\hline $\begin{array}{l}\text { Chinn-Ito index } \times \text { Capital } \\
\text { regulatory index dummy }\end{array}$ & $\begin{array}{l}0.505^{\star \star \star} \\
(0.16)\end{array}$ & $\begin{array}{c}0.487^{\star \star \star} \\
(0.17)\end{array}$ & $\begin{array}{l}0.512^{\star *} \\
(0.19)\end{array}$ & $\begin{array}{c}0.600^{\star * *} \\
(0.21)\end{array}$ & $\begin{array}{c}0.590 * \star \star \\
(0.19)\end{array}$ \\
\hline Capital regulatory index dummy & $\begin{array}{l}0.005 \\
(0.27)\end{array}$ & $\begin{array}{l}0.174 \\
(0.23)\end{array}$ & $\begin{array}{l}0.032 \\
(0.45)\end{array}$ & $\begin{array}{l}-0.195 \\
(0.45)\end{array}$ & $\begin{array}{l}-0.116 \\
(0.43)\end{array}$ \\
\hline Bank controls & & & & & \\
\hline Size & $\begin{array}{l}-0.081 \\
(0.52)\end{array}$ & $\begin{array}{l}-0.112 \\
(0.50)\end{array}$ & $\begin{array}{l}-0.111 \\
(0.50)\end{array}$ & $\begin{array}{l}0.020 \\
(0.70)\end{array}$ & $\begin{array}{l}0.095 \\
(0.65)\end{array}$ \\
\hline Capital ratio & $\begin{array}{c}-0.184^{\star \star \star} \\
(0.06)\end{array}$ & $\begin{array}{c}-0.193^{\star \star \star} \\
(0.05)\end{array}$ & $\begin{array}{c}-0.194^{\star \star *} \\
(0.05)\end{array}$ & $\begin{array}{c}-0.218^{\star \star \star} \\
(0.06)\end{array}$ & $\begin{array}{c}-0.217^{\star \star *} \\
(0.06)\end{array}$ \\
\hline Liquidity ratio & $\begin{array}{l}0.002 \\
(0.02)\end{array}$ & $\begin{array}{l}0.002 \\
(0.02)\end{array}$ & $\begin{array}{l}0.002 \\
(0.02)\end{array}$ & $\begin{array}{l}0.007 \\
(0.02)\end{array}$ & $\begin{array}{l}0.006 \\
(0.02)\end{array}$ \\
\hline Loan loss reserve ratio & $\begin{array}{l}0.072^{*} \\
(0.04)\end{array}$ & $\begin{array}{l}0.053 \\
(0.05)\end{array}$ & $\begin{array}{l}0.053 \\
(0.05)\end{array}$ & $\begin{array}{l}0.070 \\
(0.06)\end{array}$ & $\begin{array}{l}0.066 \\
(0.06)\end{array}$ \\
\hline Solvency ratio & $\begin{array}{l}0.010 \\
(0.01)\end{array}$ & $\begin{array}{l}0.011^{*} \\
(0.01)\end{array}$ & $\begin{array}{l}0.011^{*} \\
(0.01)\end{array}$ & $\begin{array}{l}0.010 \\
(0.01)\end{array}$ & $\begin{array}{l}0.010 \\
(0.01)\end{array}$ \\
\hline ROAE & $\begin{array}{c}0.026^{* * *} \\
(0.01)\end{array}$ & $\begin{array}{c}0.025^{\star * *} \\
(0.01)\end{array}$ & $\begin{array}{c}0.025^{\star \star *} \\
(0.01)\end{array}$ & $\begin{array}{c}0.026^{* * *} \\
(0.01)\end{array}$ & $\begin{array}{c}0.026^{* * *} \\
(0.01)\end{array}$ \\
\hline Macro controls & & & & & \\
\hline Concentration & & $\begin{array}{l}0.025 \\
(0.03)\end{array}$ & $\begin{array}{l}0.028 \\
(0.03)\end{array}$ & $\begin{array}{l}0.038 \\
(0.04)\end{array}$ & $\begin{array}{l}0.036 \\
(0.04)\end{array}$ \\
\hline
\end{tabular}
nature and source of capital.

Table 9. Systemic vulnerability, financial openness and capital regulations 


\begin{tabular}{|c|c|c|c|c|c|}
\hline VARIABLES & $\begin{array}{c}(1) \\
\text { Systemic } \\
\text { vulnerability }\end{array}$ & $\begin{array}{c}(2) \\
\text { Systemic } \\
\text { vulnerability }\end{array}$ & $\begin{array}{c}(3) \\
\text { Systemic } \\
\text { vulnerability }\end{array}$ & $\begin{array}{c}(4) \\
\text { Systemic } \\
\text { vulnerability }\end{array}$ & $\begin{array}{c}(5) \\
\text { Systemic } \\
\text { vulnerability }\end{array}$ \\
\hline Regulatory index & & & $\begin{array}{l}0.529 \\
(1.19)\end{array}$ & $\begin{array}{l}1.256 \\
(1.43)\end{array}$ & $\begin{array}{l}0.866 \\
(1.43)\end{array}$ \\
\hline GDP growth & & & & $\begin{array}{l}0.015 \\
(0.01)\end{array}$ & $\begin{array}{l}0.017 \\
(0.01)\end{array}$ \\
\hline Inflation & & & & & $\begin{array}{c}-0.022 \\
(0.02)\end{array}$ \\
\hline Observations & 292 & 292 & 292 & 269 & 269 \\
\hline R-squared & 0.415 & 0.419 & 0.419 & 0.455 & 0.456 \\
\hline Number of banks & 25 & 25 & 25 & 25 & 25 \\
\hline Number of countries & 10 & 10 & 10 & 10 & 10 \\
\hline Time FE & YES & YES & YES & YES & YES \\
\hline Country FE & YES & YES & YES & YES & YES \\
\hline Cluster & Bank & Bank & Bank & Bank & Bank \\
\hline
\end{tabular}

Note: This table reports the estimation results of the following empirical model:

Systemic vulnerability $y_{j i t}=\beta_{0}+\beta_{1} \times$ Financial openness $_{j, t-1}+\beta_{2} \times$ Financial openness $_{j, t-1} \times$ Capital regulatory

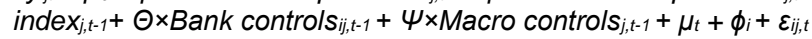

The method used is OLS Fixed Effects. The sample includes 25 banks from 10 countries of Central and Eastern Europe analyzed during 2005-2012. The dependent variable is Systemic vulnerability of bank i's from country $\mathrm{j}$ in quarter $\mathrm{t}$ (expressed in units of median \% loss of the banks' market assets within a quarter). Explanatory variables are lagged one period. All specifications include bank fixed effects, time fixed effects and an unreported constant. Variables are winsorized within the $1 \%$ and $99 \%$ percentiles, their definition being provided in Table 1 . Standard errors clustered at bank level are reported in brackets. ${ }^{*}$, ** and ${ }^{* * *}$ denote significance levels of $10 \%, 5 \%$ and $1 \%$.

Finally, the Chinn-Ito financial openness index is interacted with the private monitoring dummy. The variable takes the value 1 if the median of Private monitoring index is above the median value for entire sample of banks and 0 otherwise. Private monitoring index reflects how much the regulatory and supervisory actions encourage the monitoring of banks by private investors. The index takes values from 0 to 12 , with higher values pointing towards a greater regulatory empowerment of banks' private monitoring.

Systemic vulnerability ${ }_{i j t}=\beta_{0}+\beta_{1} \times$ Financial openness $j, t-1+\beta_{2} \times$ Financial openness $s_{j, t-1} \times$ Private monitoring index $x_{j, t-1}+\Theta \times$ Bank controlsij,t-1 $+\Psi \times$ Macro controls $j, t-1+\mu_{t}+\phi_{i}+\varepsilon_{i j, t}$

Table 10. Systemic vulnerability, financial openness and private monitoring

\begin{tabular}{lccccc}
\hline & $(1)$ & $(2)$ & $(3)$ & $(4)$ & $(5)$ \\
VARIABLES & $\begin{array}{c}\text { Systemic } \\
\text { vulnerability }\end{array}$ & $\begin{array}{c}\text { Systemic } \\
\text { vulnerability }\end{array}$ & $\begin{array}{c}\text { Systemic } \\
\text { vulnerability }\end{array}$ & $\begin{array}{c}\text { Systemic } \\
\text { vulnerability vulnerability }\end{array}$ \\
\hline
\end{tabular}

Financial openness

Chinn-Ito index

$\begin{array}{cc}0.897^{\star \star *} & 0.830^{\star *} \\ (0.23) & (0.36)\end{array}$

$1.146^{\star \star \star}$

$1.888^{* * *}$

$1.833^{* \star *}$

$(0.23)$

$(0.38)$

$(0.55)$

(0.56) 
(1)

(2)

(3)

(4)

(5)

VARIABLES

Systemic Systemic Systemic Systemic Systemic

Chinn-Ito index $\times$ Private vulnerability vulnerability vulnerability vulnerability vulnerability

monitoring index dummy

$\begin{array}{lllll}0.798^{\star *} & 0.819^{\star *} & 1.099^{\star \star *} & 1.061^{* * *} & 1.087^{\star * *}\end{array}$

$(0.34)$

(0.25)

$(0.25)$

(0.26)

Private monitoring index

dummv

$-1.000^{* *}$

-0.960 ***

$-2.613^{* * *}$

$-2.603^{\star \star *}$

$-2.599^{\star * \star}$

(0.37)

(0.33)

(0.51)

(0.52)

(0.49)

Bank controls

Size

$-0.034$

$-0.193$

0.063

0.149

Capital ratio

(0.43)

$(0.42)$

$(0.57)$

(0.51)

$-0.208^{* * *}$

$-0.212^{\star \star *}$

$-0.222^{* * *}$

$-0.247^{\star \star \star}$

$-0.245^{\text {*** }}$

Liquidity ratio

(0.05)

(0.06)

(0.06)

(0.06)

0.002

0.002

0.005

0.009

0.009

(0.02)

$(0.02)$

(0.01)

(0.02)

(0.02)

Loan loss reserve ratio

0.031

0.026

0.015

0.029

0.024

$(0.03)$

$(0.04)$

$(0.04)$

(0.06)

(0.06)

Solvency ratio

$0.013^{*}$

$0.013^{* *}$

$0.013^{* *}$

$0.012^{*}$

$0.012^{*}$

$(0.01)$

(0.01)

$0.026^{\star \star \star}$

$0.026^{* * *}$

$(0.01)$

(0.01)

ROAE

(0.01)

$(0.01)$

$0.022^{\star \star \star}$

$0.022^{\star * *}$

$0.022^{\star \star \star}$

(0.01)

$(0.01)$

(0.01)

Macro controls

Concentration

0.009
$(0.04)$

0.035

0.048

0.047

(0.03)

$(0.04)$

(0.04)

Regulatory index

$6.075^{\star \star *}$

$6.584^{\star * *}$

$6.311^{\star \star *}$

(1.59)

(1.76)

(1.86)

0.010

0.013

(0.01)

$(0.01)$

$-0.023$

(0.02)

Observations

R-squared

292

0.417

292

292

269

269

25

0.417

Number of banks

10

25

0.459

0.487

0.488

Number of countries

YES

10

25

10

25

25

10

10

Time FE

YES

YES

YES

YES

Country FE

YES

YES

YES

YES

Cluster

Bank

Bank

Bank

Bank

Bank

Note: This table reports the estimation results of the following empirical model:

Systemic vulnerability $y_{j t}=\beta_{0}+\beta_{1} \times$ Financial openness ${ }_{j, t-1}+\beta_{2} \times$ Financial openness ${ }_{j, t-1} \times$ Private

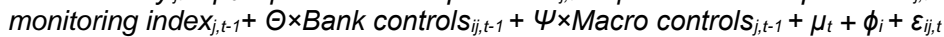

The method used is OLS Fixed Effects. The sample includes 25 banks from 10 countries of Central and Eastern Europe analyzed during 2005-2012. The dependent variable is Systemic vulnerability of bank i's from country $\mathrm{j}$ in quarter $\mathrm{t}$ (expressed in units of median \% loss of the banks' market assets within a quarter). Explanatory variables are lagged one period. All specifications include bank fixed effects, time fixed effects and an unreported constant. Variables are winsorized within the $1 \%$ and $99 \%$ percentiles, their definition being provided in Table 1. Standard errors clustered at bank level are reported in brackets. ${ }^{*}{ }^{* \star}$ and ${ }^{\star \star \star}$ denote significance levels of $10 \%, 5 \%$ and $1 \%$. 
The results presented in Table 10 shows that the interaction between the ChinnIto index and private monitoring dummy is positive and statistically significant. This suggests that the harmful impact of a higher degree of capital accounts openness on banks' vulnerability is greater for banks from countries with stronger regulatory and supervisory actions that encourage the monitoring of banks by private investors.

\section{Conclusions}

This paper investigates the impact of financial openness on banks' exposure to extreme events (the vulnerability of banks' market assets to a downturn in the total market assets of the system). The sample we focus on includes several of the most important banks from CEE area with a high share in total banking assets at the country level that are analyzed during the period 2005-2012. Firstly, we estimate banks' systemic vulnerability based on the distributions of banks' and system's market assets returns using Quantile Regression models. Secondly, using an Ordinary Least Square model with FE we investigate the impact of the degree of capital account openness at the country level on banks' systemic vulnerability (de jure financial openness).

The output highlights a positive impact of a higher degree of capital account openness on banks' systemic vulnerability that is strongly significant. A one standard deviation increase in the Chinn-Ito index generates about 25 percent standard deviation increase in the systemic vulnerability index. The results are robust to different specifications that account for macroeconomic environment and bank characteristics, as well as for an asymmetric extension of the systemic vulnerability index.

We also explore the effects of ownership, Vienna initiative commitments, capital regulations and private monitoring. Robust findings suggest that the harmful effect of less stringent restrictions related to cross-border capital transactions on banks' vulnerability is lower for foreign owned banks or for those whose bank holding company signed one or more Vienna Initiative commitment letters. On the other hand, the positive impact of a higher degree of capital accounts openness on banks' vulnerability to systemic events is higher in countries with tighter capital regulations and private monitoring policies.

A limitation of this study can be attributed to possible macroeconomic shocks in the home countries of parent banks with subsidiaries in emerging countries during turbulent periods. For example, macroeconomic conditions deteriorated significantly during the period analyzed in developed European countries with subsidiaries in CEE. Also bad performance at the level of bank holding company or excessive risk taking can rapidly spread to the balance sheet level of the subsidiaries, thus reducing their resilience to systemic events. An interesting topic for future research would be to assess the impact of macroeconomic shocks in the home countries of parent banks with subsidiaries in CEE region on the nexus between host countries financial openness and systemic vulnerability. Also, from a microprudential perspective, it would be useful to investigate how balance sheet shocks at the level of bank holding companies affect the relationship between financial openness and subsidiaries exposure to systemic events.

Acknowledgment: This work was supported by a grant of the Romanian National Authority for Scientific Research and Innovation, BRIDGE GRANT DSS-Direct, project number PN-III-P2-2.1-BG-2016-0447. 


\section{References}

Acemoglu, D., A. Ozdaglar, and A. Tahbaz-Salehi (2015) Systemic risk and stability in financial networks, American Economic Association, 105 (2), 564-608.

Acharya, V. V., Engle, R. F. and Richardson, M. (2012) Capital Shortfall: A new approach to ranking and regulating systemic risks, American Economic Review, 102 (3), 59-64.

Adams, Z., Füss, R. and Gropp, R. (2014) Spillover effects among financial institutions: A State-Dependent Sensitivity Value-at-Risk (SDSVaR) approach, Journal of Financial and Quantitative Analysis, 49, 575-598.

Adrian, T., Brunnermeier, M. (2016) CoVaR, American Economic Review, 106 (7), 170541.

Adrian, T., Shin, H.S. (2010) Liquidity and leverage, Journal of Financial Intermediation, 19 (3), 418-437.

Allen, F., and D. Gale (2000) Financial contagion, Journal of Political Economy, 108,1-33.

Allen, F., Gale, D. (2007) Understanding financial crises, Clarendon Lecture Series in Finance, Oxford: Oxford University Press.

Anginer, D., Demirgüç-Kunt, A., Zhu, M. (2014) How does deposit insurance affect bank risk? Evidence from the recent crisis, Journal of Banking and Finance, 48, 312-321.

Babus, A. (2016) The formation of financial networks, Journal of Economics, 47, 239-272.

Barth, J.R., Caprio, G., Levine, R. (2013) Bank regulation and supervision in 180 countries from 1999 to 2011, Journal of Financial Economic Policy, 5 (2), 111-219.

Betz, F., Hautsch, N., Peltonen, T.A. and Schienle, M. (2016) Systemic risk spillovers in the European banking and sovereign network, Journal of Financial Stability, 25, 206-224.

Bostandzic, D., Pelster, M., Weiß, G.N.F. (2014) Systemic risk, bank capital, and deposit insurance around the world, Working Paper TU Dortmund University.

Brunnermeier, M. and Pedersen, L.H. (2009) Market liquidity and funding liquidity, The Review of Financial Studies, 22, 2201-2238.

Chinn, M.D., Ito H. (2006) What matters for financial development? Capital controls, institutions, and interactions, Journal of Development Economics, 81 (1), 163-192.

Chinn, M.D., Ito H. (2008) A new measure of financial openness, Journal of Comparative Policy Analysis, 10 (3), 309-322.

Cifuentes, R., G. Ferrucci, and H. S. Shin (2005) Liquidity risk and contagion, Journal of European Economic Association, 3(2), 556-566.

Cont, R., Moussa, A. and Santos, E.B. (2013) Network structure and systemic risk in banking systems. In: Langsam, J.-P., an Fouque, J.A. (Eds.), Handbook on Systemic Risk. Cambridge University Press, pp. 327-368.

Correa, R., Lee, K.H., Sapriza, H., Suarez, G.A. (2014) Sovereign credit risk, banks' government support and bank stock returns around the world, Journal of Money, Credit and Banking, 46 (1), 93-121.

Dasgupta, A. (2004) Financial contagion through capital connections: A model of the origin and spread of bank panics, Journal of the European Economic Association, 2 (6), 1542-4774.

Drehmann, M. and Tarashev, N. (2013) Measuring the systemic importance of interconnected banks, Journal of Financial Intermediation, 22 (4), 586-607. 
Filipović, D.and Trolle, A.B. (2013) The term structure of interbank risk, Journal of Financial Economics, 109 (4), 707-733.

Freixas, X., B. Parigi, and J. C. Rochet (2000) Systemic risk, interbank relations and liquidity provision by the central bank, Journal of Money, Credit and Banking, 32, 611-638.

Hautsch, N., Schaumburg, J. and Schienle, M. (2015) Financial network systemic risk contributions, Review of Finance, 19, 685-738.

Minoiu, C., Kang, C., Subrahmanian, V.S. and Berea, A. (2015) Does financial connectedness predicts crises?, Quantitative Finance, 15 (4), 607-624.

Weiß, G.N.F., Bostandzic, D. and Neumann, S. (2014) What factors drive systemic risk during international financial crises?, Journal of Banking and Finance, 41, 78-96. 